American Journal of Biochemistry and Biotechnology 8 (1): 25-37, 2012

ISSN 1553-3468

(C) 2012 M.I.K. El-Sayed et al., This open access article is distributed under a Creative Commons Attribution

(CC-BY) 3.0 license

\title{
Anti-Microbial, Anti-Oxidant and Anti-Ulcerogenic Effects of Shilajit on Gastric Ulcer in Rats
}

\author{
${ }^{1}$ Mohamed-I. Kotb El-Sayed, ${ }^{1}$ Hatem-K. Amin and ${ }^{2}$ Ali-G. Al-Kaf \\ ${ }^{1}$ Department of Biochemistry and Molecular Biology, Faculty of Pharmacy, \\ Helwan University, Ain Helwan, Helwan P.O. Box 11790, Cairo, Egypt \\ ${ }^{2}$ Department of Medicinal Chemistry, Faculty of Pharmacy, \\ Sana'a University, Madbah, P.O. Box 19065, Sana'a, Yemen
}

\begin{abstract}
Problem statement: To evaluate the effects and mechanisms of action involved in anti-ulcer, antioxidant and antimicrobial activities of different native shilajit samples. Approach: Shilajit samples were collected in the mountain region of Yemen (Al-Jouf and Rayma), Russia (Tien-Shan) and India (Kumoan). Stomach ulcers were induced in rats by oro-gastric ingestion of ethanol/HCl. Pre-treatment with ranitidine (100 mg kg-1 , p.o.) and shilajit samples $\left(600 \mathrm{mg} \mathrm{kg}^{-1}\right.$, p.o.) occurred for 14 days before the ulcer induction. Plasma lipids, TBARs, SOD, GSH, catalase activity and gastric mucosal histological changes in rat stomach tissue were evaluated. Antimicrobial efficacy of shilajit $\left(500,300\right.$ and $\left.100 \mu \mathrm{g} \mathrm{disc}^{-1}\right)$ was also studied against fungi, gram positive and negative bacteria. Results: Data had shown the hypo-lipidemic and antioxidant effects of studied shilajit samples on ethanol/HCl-induced ulcer model via decreasing TGs, Tc, TBARs while increasing HDLc, SOD, catalase and GSH than saline or ranitidine pre-treated groups. AlJouf and Indian shilajit samples inhibit both ulcer score and lesion area by greater percentages than either ranitidine or other samples. Rayma and Russian samples showed a strongest antimicrobial effect than either Al-Jouf or Indian samples. Conclusion/Recommendations: Some of studied shilajit samples have antioxidant and anti-ulcer against induced gastric ulcer, while others showed anti-microbial activities against tested microbes; mightily due to combined mechanisms of shilajit's constituents, including hypolipidemic, antioxidant, anti-inflammatory, anti-stress, anti-anxiety, regenerative, repairing and healing mechanisms.
\end{abstract}

Key words: Anti-oxidant, anti-microbial, anti-ulcer, fulvic acid, shilajit

\section{INTRODUCTION}

Shilajit is a herbo-mineral, marine animal origindead/fossil invertebrates, semi-hard brownish black resin formed through long-term humification of several plant types, mainly bryophytes such as Euphorbia and Trifolium (clover) plants and lichen, present in the vicinity of shilajit-exuding rocks. This plant type of shilajit called Mumie-asil to being distinguished from other types (petroleum mumie and mumiekiem). It has common names; vegetable asphalt, mineral pitch, mountain sweat, mountain oil, rock juice. The name "mumie, hajar-musa or mumia" was devised by the Arabs and in ancient Egypt, this wonderful resin was used for embalming mummies (Schepetkin et al., 2003; Talbert, 2004; Ali et al., 2005; Agarwal et al., 2007).

It is found in specific mountain regions of the world at altitudes between 0.6 and $5 \mathrm{~km}$ on the walls of caves, embedded in rocks or as rock exudates and can exceed $500 \mathrm{~kg}$ in weight; in Kashmir, Afghanistan, Nepal, Bhutan, Pakistan, China, Tibet,
Yemen, Asian parts of Russia and neighboring areas (Ghosal et al., 1991; Agarwal et al., 2007). Its samples from different regions of the world have similar physical properties and qualitative chemical composition but they differ in the ratio of individual components (Galimov et al., 1986).

Shilajit humus consists of organic matter (60-80\%), mineral matter $(20-40 \%)$ and $5 \%$ trace elements. The main chemical components of shilajit are humic acid, fulvic acid, benzoic acid, benzoates and high concentration of vitamin A, B, C esters (Schepetkin et al., 2002). Modern chemical analyses identified six new compounds named as shilajityl acetate, shilajitol, shilacatechol, shilaxanthone, shilanthranil and naphsilajitone along with pyrocatechol and their stereostructures (Ali et al., 2005).

It traditionally used for obstinate diseases including; tuberculosis, cervical lymphadenitis, diabetes mellitus-type I, digestive disorders, cough, obesity, hemorrhoids, Jaundice, poison begotten distempers and internal tumors (Murthy, 1995).

Corresponding Author: Mohamed-I. Kotb El-Sayed, Department of Biochemistry and Molecular Biology, Faculty of Pharmacy, Helwan University, Ain Helwan, Helwan P.O. Box 11790, Cairo, Egypt Tel: +20114-0400-767 Fax: +202-2554-1601 
Mucosal injury may occur when noxious factors "overwhelm" an intact mucosal defense or when the mucosal defense is somehow impaired (Laine et al., 2008). Ethanol induced gastric damage has been soon to be associated with depletion of gastric mucus breaking of the mucosal barrier, back diffusion of acid, increased gastric mucosal permeability, leads to increasing leak of hydrogen ion from the lumen ,decrease in the transmucosal electrical potential difference, changes in the mucosal blood flow, destruction of micro-vascular and nonvascular type of cells, mast cell degranulation, neutrophill mediated mucosal injury (release of oxygen free radicals, proteases and lysosomal enzymes, digestion of proteins and lipid peroxidation in cell membrane) and depletion of certain oxygen free radical scavenger (Akilandeswari et al., 2010).

Peptic ulcer being one of the most uncontrolled gastrointestinal disorders representing a major health hazards in terms of morbidity and mortality (Goel and Bhattacharya, 1991; Akhtar et al., 1992). Common antiulcer drugs include $\mathrm{H} 2$ receptor antagonists, proton pump inhibitors or cytoprotective agents such as sucralfate. Patients used these drugs suffering severe side effects like arrythmias, gynaecomastia, enterochromaffin like cell hyperplasia and hematopoietic changes (Akhtar et al., 1992).

The present study aimed to compare among shilajit samples of different native origin \{Yemen (Al-Jouf and Rayma), Russia (Tien-Shan) and India (Kumoan) \} in: antimicrobial antioxidant and gastro-protective activity against ethanol/ $\mathrm{HCl}$ induced gastric ulcer in rat.

\section{MATERIALS AND METHODS}

Chemicals, solutions and equipments: Ranitidine powder as hydrochloride (Shiba Pharma, ceuticals and chemicals Mgf. Ltd. Yemen); ferrous sulfate $\left(\mathrm{FeSO}_{4}\right)$; Carboxy-Methylcellulose $\quad 0.5 \% \quad$ (CMC); sodium chloride (WAKO Pure Chemical Industries, Osaka, Japan); perchloric acid $\left(\mathrm{HClO}_{4}\right)$ and Thiobarbituric Acid (TBA) (Sigma, St. Louis, MO, USA); Hydrochloride ( $\mathrm{HCl})$ (Nakarai Tesque, Ltd., Kyoto, Japan); n-butanol and Sodium Dodecyl Sulfate (SDS) (Life Technologies Japan Ltd., Tokyo, Japan). Absolute ethanol (@Merk KGaA, Darmstadt, Germany); Kits of triglycerides (TGs), total cholesterol $\left(\mathrm{T}_{\mathrm{C}}\right)$, High Density Lipoprotein cholesterol $\left(\mathrm{HDL}_{\mathrm{C}}\right)$ (Beijing Chengxinde Biochemistry Reagent Company, China); Hematoxylin/eosin, xylene and formalin; Mueller Hinton agar (Oxoid CM337, Basingstoke, Hampshire, UK). Drugs and chemicals were dissolved in analytical grade buffers and solvents and prepared upon usage. Stomach tube; Microtome, Rotary evaporator; mortar and pestle; wattman filter paper; Petri-dishes; autoclave; Hiscotron homogenizer; electric balance
(Sartorius AG, Gottingen, Germany, BP310S); centrifuge (HERNIE Z 400, Wehingen); UV/Visible spectrophotometer (Shimadzu); micropipette of different size; deep freeze.

Preparation and purification of shilajit samples: Shilajit was collected in the mountain region of Yemen (Al-Jouf and Rayma), Russia (Tien-Shan) and India (Kumoan). Purification of shilajit samples was done according to the principle of the solubility in distilled water as described by Jung et al. (2002). All samples of shilajit were milled to very small pieces, then weighing $100 \mathrm{gm}$ of each sample and transferred to the volumetric flasks, then, $500 \mathrm{~mL}$ of distilled water were added and flasks were putted on a shaker for $10 \mathrm{~h}$ at room temperature. After that, sample solutions were purified by filtration through $0.45-\mathrm{mm}$ filter to remove the insoluble impurities. The extract was dried; $100 \mathrm{~mL}$ of each sample was placed in Rotary evaporator and evaporating the solvent by reducing the pressure to avoid the decomposition of shilajit constituents and purified samples were attained. For the biological experiments, the dried shilajit extract was suspended in a balanced salt solution and filtrated through a $0.2-\mathrm{mm}$ filter.

\section{Antiulcer activity:}

Experimental animals: 72 healthy Waster Albino rats and 130 Swiss Albino mice of both sexes were obtained from Central Animal House of the Science College in Sana'a University. The animals were housed and fed with standard pellet diet and water ad libitum. Animals were allowed to acclimatize in the local laboratory for 1 week prior to the experimentation. They were housed group wise in polypropylene cage $(17 \times 11 \times 6)$ and kept under controlled environmental conditions (temperature: $22 \pm 2^{\circ} \mathrm{C}$, humidity: $50-55 \%$, natural light/dark cycle). Coprophagy was prevented by keeping the animals in cages with grating as the floor. The protocol of the study was following the local institutional animal ethical committee, for the care and use of laboratory animals.

Experimental design: 72 Wister albino rat (weighing between 200-250 g) and 130 Swiss albino mice (weighing between 25-35 g) of either sex were used for antiulcer and toxicity studies respectively. Mice were divided into 13 groups of 10 animals (5 males and 5 females) and rats into 6 groups of 12 animals (6 males and 6 females). Fresh conventional antiulcer drug (Ranitidine) and shilajit solutions were prepared fresh at the time of administration. All animals were deprived of food at least $36 \mathrm{hr}$ before start of either acute oral toxicity or intra-gastric ulcer induction experiment but allowed free access of water and returned to diet just after beginning of the toxicity experiment while killed later $4 \mathrm{~h}$ after intra-gastric induction experiment. All 
experiments were performed during light phase between 9.30 AM-3.30 PM.

Group designing for acute oral toxicity study: Toxicity study was undertaken on 130 adult Swiss albino mice using 300, 600 and $900 \mathrm{mg} \mathrm{kg}^{-1}$ of different 4 shilajit samples suspended in $1 \%$ Carboxy Methyl Cellulose (CMC) which administered (p.o.) daily for 10 days (13 group; 10 mice for each, saline group, 3 groups for each shilajit sample) and animals receiving saline $0.9 \%$ served as control. The signs and symptoms associated with the shilajit administration were observed at $0,30,60,120,180$ and $240 \mathrm{~min}$ after and then once a day for the next 10 days. At the end of the period, the number of survivors were recorded and the acute toxicological effect was estimated through the method described by Pucaj et al. (2011) to find out the safe dose.

Group designing for ethanol/HCL induced ulcer models: 72 rats were divided into six groups (12 rats for each). Saline group; animals received only one dose of saline $\left(1 \mathrm{~mL}\right.$ of $0.9 \%$ saline $\left.200 \mathrm{~g}^{-1}\right)$, Ranitidine group; animals received one dose of Ranitidine (100 mg $\mathrm{kg}^{-1}$, suspended in $1 \mathrm{~mL}$ of $1 \% \mathrm{CMC}$ ) and Shilajit groups; animals received one dose of Russian, Indian, Al-Jouf, Rayma shilajit samples respectively (600 mg $\mathrm{kg}^{-1}$, suspended in $1 \mathrm{~mL}$ of $1 \% \mathrm{CMC}$ ) per os dialy for 14 days and until 1 hour before ulcerogenic procedure. On day 14, rats were fasted (except for water and treatments) for $36 \mathrm{~h}$ before oro-gastric intubation (on

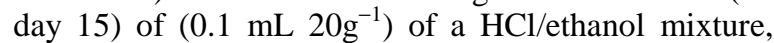
containing $150 \mathrm{mM} \mathrm{HCl}$ in $98 \%$ ethanol (Shujaa et al., 2009) for each rat $1 \mathrm{hr}$ after respective dosing.

\section{Biochemical, morphological and histological examinations of stomach:}

Plasma lipids: $4 \mathrm{hr}$ after ulcerogenic procedure, the animals were sacrificed by spinal incapitation and blood taken on heparinized tubes to separate plasma for colorimetric estimation of TGs using the phosphate oxidase method as described by Trinder (1969), total cholesterol using the Chod-Pap method as described by Zoppi and Fellini (1976) and HDL $_{C}$ using the dextran-sulphate $\mathrm{Mg}$ (II) method as described by Wieland and Siedel (1981).

Morphological examination of stomach: Stomachs were removed, placed on ice-cold normal saline, opened along the greater curvature, washed with normal saline and observed for the severity of the ulcers by measuring both gastric lesion Ulcer Index (ULI) and Ulcer Score (US). Ulcers of the gastric mucosa appear as elongated bands of hemorrhagic lesions parallel to the long axis of the stomach. The mucosal layer of stomach was observed under magnifying lens and was checked for ulcers, hemorrhagic areas perforations. The length and width of the ulcer $(\mathrm{mm})$ were measured by a planimeter $\left(10 \times 10 \mathrm{~mm}^{2}\right)$. The ulcerated area was measured by counting the number of small squares, $2 \times 2$ $\mathrm{mm}$, covering the length and width of each ulcer band. The sum of the areas of all lesions for each stomach was applied in the calculation of ULI. The ulcer index was determined as ULI $=10 / \mathrm{X}$ Where $\mathrm{X}=$ Total area of stomach mucosa / Total ulcerate area) (Rainsford, 1984).

Evaluation of gastric mucosa for the presence of gastric ulcer using ulcer score; the severity of hemorrhagic section in the acid secreting glandular mucosa was done on a scale of $0-5$ score $[0=$ No erosion, 1= Normal, 2= Hyperemia or thinness, 3= Superficial mucosal erosion, $4=$ Deep ulcer or transmascular necrosis and 5= Perfusion] as described by Piezzi et al. (1992).

Histological examination of stomach: Stomach portion of each rat was used for histological examination. Gastric tissue samples were fixed in neutral buffered formalin for $24 \mathrm{~h}$. Stomach sections (three for each group) were dehydrated with graded ethanol, passed through xylene and embedded in paraffin. The three paraffin sections (of $5 \mu \mathrm{m}$ in thickness of each pretreated group were stained with Hematoxylin/Eosin (HE) staining and the slides were viewed under a light microscope equipped for photography (Oyagi et al., 2010).

Tissue lipid peroxidation and antioxidant markers: After morphological and histological examination of stomach, a weighed portion of the stomach was taken and used for estimation of gastric mucosal lipid peroxidation (thiobarbituric acid reactive substance; TBARs) and reduced glutathione (GSH) as described by Ohkawa et al. (1979) and Sedlak and Lindsay (1968) respectively (expressed as $\mathrm{n}$ moles/g wet tissue), Catalase activity (Link, 1988), antioxidant factor's Super Oxide Dismutase activity (SOD) (Elstner and Heupel, 1976) and total proteins (Lowry et al., 1951) were estimated in the gastric mucosal homogenate in ice-cold normal saline.

\section{Anti-microbial activity:}

Microbial strains: Tested microbial strains; Staphylococcus aureus, Bacillus subtilis (Gram positive), Pseudomonas aeruginosa, Escherichia coli (Gram negative) and Candida albicans (Fungi) were obtained from the stock cultures of Microbiology Laboratory of Al-Kuwait Hospital, Sana'a of Yemen. A loop full of strain was inoculated in $25 \mathrm{~mL}$ of nutrient broth/Sabouraud dextrose broth in a conical flask and incubated at room temperature on a rotary shaker over night to activate the test microbial strains. The 
inoculum's size was $1 \times 10^{8}$ cells $\mathrm{mL}^{-1}$. Muller Hinton No. 2/ Sabouraud dextrose agar (Hi-media) was used for the antibacterial and antifungal susceptibility test, respectively. The microorganisms studied are clinically important ones causing several infections, food born diseases, spoilages, skin infection and it is essential to overcome them through some active therapeutic agents.

\section{Anti-microbial assay:}

Agar well diffusion method: The antimicrobial activity was tested against all the microorganisms by agar well diffusion method (Kaneria et al., 2009). For screening, required wells of $6 \mathrm{~mm}$ in diameter and about $2 \mathrm{~cm}$ apart were punctured in the culture media using sterile cork bores. $10 \mathrm{mg}$ of the shilajit was suspended in $500 \mu \mathrm{L}$ of water so as to get a concentration of $20 \mu \mathrm{g}$ in $1 \mu \mathrm{L}$ of the suspension. $5 \mu \mathrm{L}$ $\left(100 \mu \mathrm{g} \mathrm{disc}^{-1}\right), 15 \mu \mathrm{L}\left(300 \mu \mathrm{g} \mathrm{disc}{ }^{-1}\right)$ and $25 \mu \mathrm{L}(500$ $\left.\mu \mathrm{g} \mathrm{disc}^{-1}\right)$ volume of each shilajit extract was loaded on to sterile discs to each well. Water was used as the negative control. The plates were incubated at $37 / 28^{\circ} \mathrm{C}$ for $24 / 48 \mathrm{~h}$ for bacteria and fungi, respectively. After incubation period the antimicrobial activity was evaluated by measuring diameter of inhibition zones. The experiment was performed three times to minimize the error and the mean values \pm S.E.M. are presented. Netilmicin $\left(30 \mu \mathrm{g} \mathrm{disc}^{-1}\right)$, amoxicillin-clavulanic acid (20-0 $\left.\mu \mathrm{g} \mathrm{disc}^{-1}\right)$, ofloxacin $\left(5 \mu \mathrm{g} \mathrm{disc}{ }^{-1}, \mathrm{BBL}^{\mathrm{TM}}\right.$ Sensi $\left.\operatorname{disc}^{\mathrm{TM}}\right)$ and antifungal miconazole nitrate $\left(40 \mu \mathrm{g} \mathrm{disc}^{-1}\right.$, DRG International) were used as reference standards, which as recommended by the National Committee for Clinical Laboratory Standards (NCCLS).

Minimal Inhibitory Concentration (MIC): The lowest concentration or dilution of the shilajit in a serial dilution sequence that results in kills $99.9 \%$ of the test organism or the absence of its observable growth is reported as the Minimal Inhibitory Concentration (MIC). MIC was determined by dilution method as follows; thirteen screw-capped test tubes $(13 \mathrm{~mm} \times 100$ $\mathrm{mm})$ were sterilized and numbered individually. One $\mathrm{mL}$ of Mueller-Hinton/Sabouraud glucose broth was introduced into tubes \#2 to \#11. The MICs were determined from independent triplicate assays and were based on a serial 2-fold dilution starting with the initial concentration of $1000 \mu \mathrm{g} \mathrm{mL} \mathrm{mL}^{-1} .1 \mathrm{mg}(1000 \mu \mathrm{g})$ of the shilajit was suspended in $1 \mathrm{~mL}(1000 \mu \mathrm{L})$ of water so as to get a concentration of $1 \mu \mathrm{g}$ in $1 \mu \mathrm{L}$ of the suspension. To tube \#12, $2.0 \mathrm{~mL}$ of Mueller-Hinton/Sabouraud broth was introduced; $1 \mathrm{~mL}$ of the shilajit was pipetted into tube \#1 and \#2 and capped, it was vortexed for 5 seconds; $1.0 \mathrm{~mL}$ was withdrawn from the contents of tube \#2 and transferred to tube \#3, after capping the tube and mixing by shaking the contents, $1.0 \mathrm{~mL}$ from the contents of tube \#3 was withdrawn and transferred to tube \#4, the tube was capped, shaken and mixed well. This process was continued until $1.0 \mathrm{~mL}$ was withdrawn from tube \#9 and subsequently added to tube $\# 10$, capped and shaken. One $\mathrm{mL}$ of the diluted inoculum was introduced into tubes \#1 to \#11 and to tube \#13. To tube \#13,1.0 mL of the antibiotic standard was added. The tubes were incubated at $35^{\circ} \mathrm{C}$ for $18-24$ h. After incubation the tubes were examined for bacterial or fungal growth. This can be visible as turbidity in the tube or as whitish pellet at the bottom of the tube. The tube with the lowest concentration of the shilajit at which no growth or turbidity is observed was reported as the MIC against the organism (Quinto and Santos, 2005).

Statistical analysis: Results are expressed as the mean \pm S.E.M. Statistical comparisons were made using Student's t-test for paired values using SPSS program (version 15). Value of $\mathrm{P}$ less than $5 \%(\mathrm{p}<0.05)$ was considered statistically significant.

\section{RESULTS}

Shilajit purification: Shilajit samples showed peaks in the ultraviolet range at 371 and $270 \mathrm{~nm}$.

\section{Antiulcer activity:}

Toxicity evaluation: A two oral doses of shilajit (300 and $600 \mathrm{mg} \mathrm{kg}^{-1}$ ) did not produce any visible signs or symptoms of toxicity in the tested animals, while shilajit dose of $900 \mathrm{mg} \mathrm{kg}^{-1}$ slightly increase body temperature of the mice and 4 mice dead of total 40 mice for that dose of different shilajit samples. Therefore the daily dose of 600 $\mathrm{mg} \mathrm{kg}^{-1}$ was assigned for our study.

\section{Biochemical findings:}

Plasma lipids: Plasma lipids were showed a significant lower level of total plasma cholesterol in all shilajit treated groups when compared with saline pretreated group. Furthermore, Al-Jouf and Rayma shilajit pretreated group, showed highly significant drop in total plasma cholesterol level than ranitidine pretreated group. Additionally, all pretreated groups (except Russian) showed a significant increase in plasma HDLcholesterol level than saline pretreated group, while all pretreated groups (except Russian) showed a significant increase in plasma HDL-cholesterol level than ranitidine pretreated group.

Results showed a significant decrease in plasma triglycerides level in all treated groups than saline pretreated group, while all pretreated groups (except Indian and Russian) showed significant decrease in plasma triglycerides level than ranitidine pretreated group (data shown in Table 1 and Fig. 1A, 1B and 1C). 


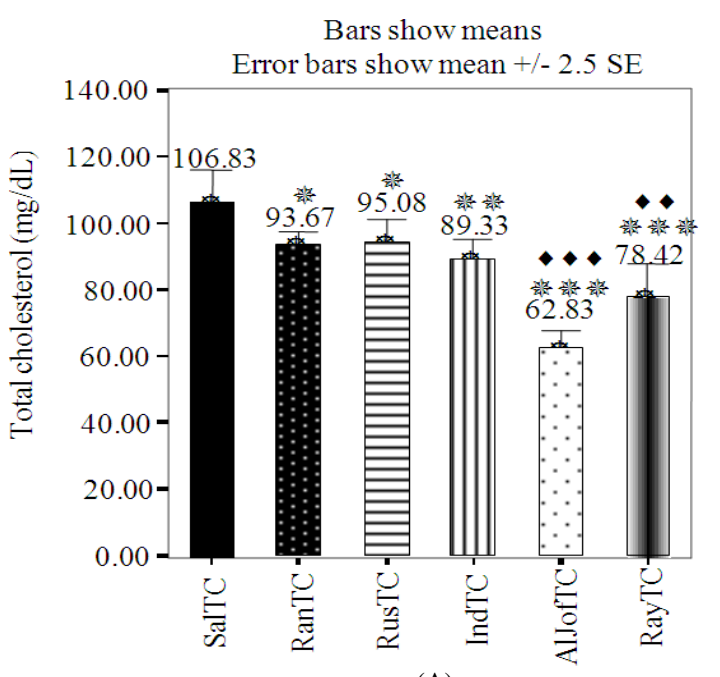

(A)

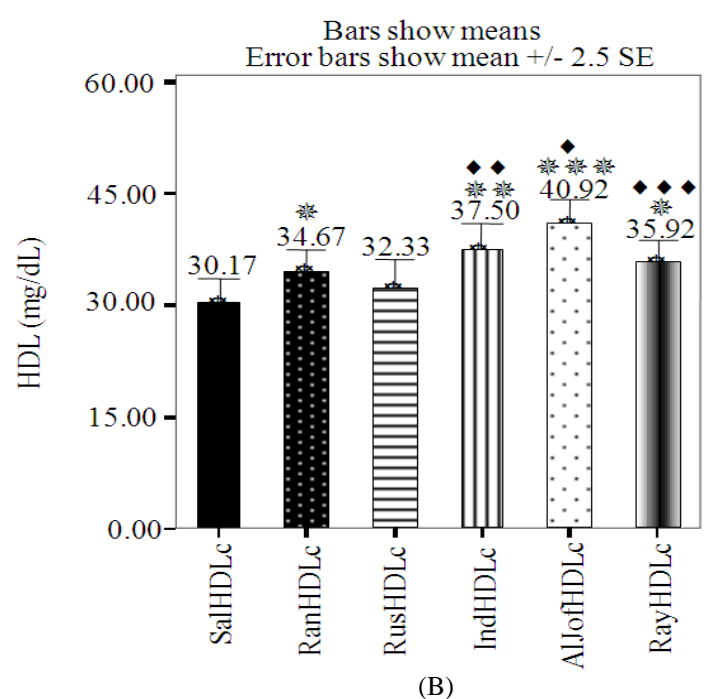

(B)

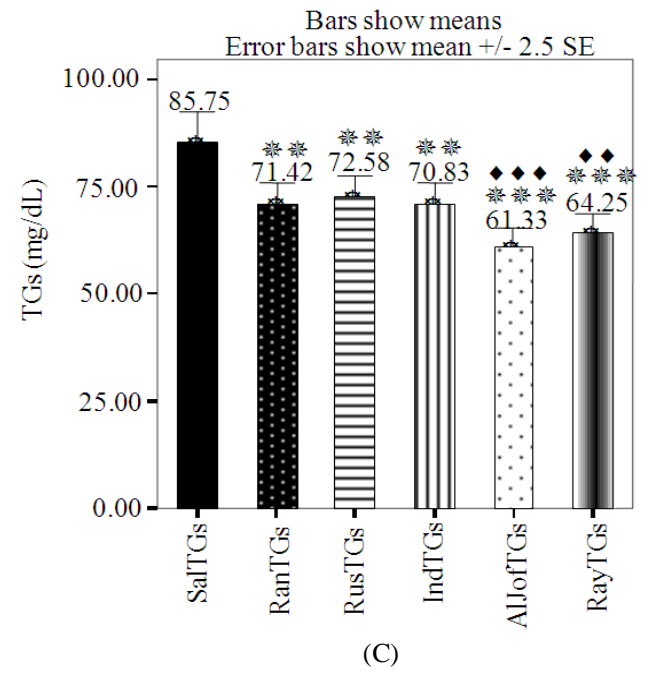

Fig. 1: Effects of shilajit samples $\left(600 \mathrm{mg} \mathrm{kg}^{-1}\right)$ and ranitidine $\left(100 \mathrm{mg} \mathrm{kg}^{-1}\right)$ pretreatment on plasma lipids $(\mathrm{A}=\mathrm{Tc}, \mathrm{B}=$ HDLc and $\mathrm{C}=\mathrm{TGs}$ ) in rats with ethanol/HCl-induced gastric ulcer. It showed significant decrease in both TGs and Tc, while increase in HDLc with treatment than saline treated group, especially in Al-Jouf and Indian shilajit treated groups. Tc $=$ total cholesterol; HDLc $=$ high density lipoprotein cholesterol; TGs = triglycerides; Sal = saline; Ran = ranitidine; Rus = Russian; Ind = Indian; AlJof = Al-Jouf; and Ray = Rayma

Table 1: Comparison of plasma lipids among different studied groups

\begin{tabular}{|c|c|c|c|}
\hline $\begin{array}{l}\text { Treatment } \\
\text { (once daily dose for } 14 \text { day) }\end{array}$ & $\mathrm{Tc}(\mathrm{mg} / \mathrm{dL})$ & $\mathrm{HDL}(\mathrm{mg} / \mathrm{dL})$ & TGs (mg/dL) \\
\hline Saline $\left(1 \mathrm{~mL} 200 \mathrm{~g}^{-1}\right.$ day $\left.^{-1}\right)$ & $106.83 \pm 3.63$ & $30.17 \pm 1.30$ & $85.75 \pm 2.70$ \\
\hline Ranitidine $\left(100 \mathrm{mg} \mathrm{Kg}^{-1}\right.$ day $\left.^{-1}\right)$ & $93.67 \pm 1.49$ 粦 & $34.67 \pm 1.07^{*}$ & $71.42 \pm 1.88^{\text {***** }}$ \\
\hline Russian $\left(600 \mathrm{mg} \mathrm{Kg}^{-1}\right.$ day $\left.^{-1}\right)$ & $95.08 \pm 2.61$ * & $32.33 \pm 1.61$ & $72.58 \pm 2.08^{\text {米粠 }}$ \\
\hline Indian $\left(600 \mathrm{mg} \mathrm{Kg}^{-1}\right.$ day $\left.^{-1}\right)$ & $89.33 \pm 2.55$ 米米 & 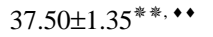 & $70.83 \pm 2.12^{* * * *}$ \\
\hline Al-Jouf $\left(600 \mathrm{mg} \mathrm{Kg}^{-1}\right.$ day $\left.^{-1}\right)$ & 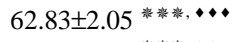 & 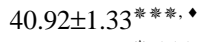 & 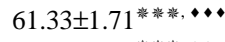 \\
\hline Rayma (600 mg Kg ${ }^{-1}$ day $\left.^{-1}\right)$ & 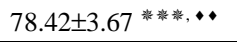 & $35.92 \pm 1.13^{*, \cdots \bullet}$ & 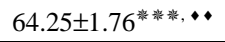 \\
\hline
\end{tabular}

The statistical data were expressed as Mean \pm S.E.M. ; number $=12$ rat for each group; $\mathrm{Tc}=$ total cholesterol; HDL $=$ high density lipoprotein

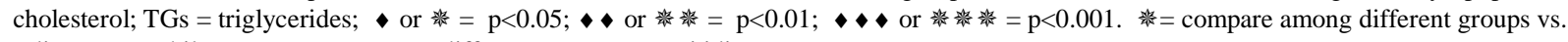
saline group while $=$ compare among different groups vs. ranitidine group 
Am. J. Biochem. \& Biotech., 8 (1): 25-37, 2012

Table 2: Comparison of stomach tissue TBARs, Catalase, SOD and GSH among different studied groups

\begin{tabular}{|c|c|c|c|c|c|}
\hline $\begin{array}{l}\text { Treatment } \\
\text { (once daily } \\
\text { dose for } 14 \text { day) }\end{array}$ & $\begin{array}{l}\text { TBARs } \\
\text { ( } \mathrm{n} \text { moles } 100 \mathrm{mg}^{-1} \\
\text { of wet tissue) }\end{array}$ & $\begin{array}{l}\text { Catalase } \\
\text { (Units/mg } \\
\text { of protein) }\end{array}$ & $\begin{array}{l}\text { SOD } \\
\text { (Units/mg } \\
\text { of protein) }\end{array}$ & $\begin{array}{l}\text { GSH } \\
\text { ( } \mu \mathrm{mol} / \mathrm{g} \text { of } \\
\text { wet tissue) }\end{array}$ & $\begin{array}{l}\mathrm{TP} \\
(\mathrm{mg} / \mathrm{ml})\end{array}$ \\
\hline 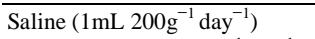 & $3.03 \pm 0.22$ & $34.75 \pm 0.91$ & $38.33 \pm 0.85$ & $289.3 \pm 2.8$ & $15.9 \pm 0.6$ \\
\hline Ranitidine $\left(100 \mathrm{mg} \mathrm{Kg}^{-1}\right.$ day $\left.^{-1}\right)$ & $0.54 \pm 0.10^{\text {䖭漛 }}$ & $39.5 \pm 1.04 *$ & $44.5 \pm 1.04^{* * *}$ & $381.6 \pm 4.27^{\text {类称 }}$ & $18.0 \pm 0.54^{\text {*** }}$ \\
\hline Russian (600 mg Kg ${ }^{-1}$ day $^{-1}$ ) & 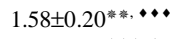 & $38.58 \pm 1.05$ & $39 \pm 1.19^{\bullet}$ & 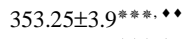 & $16.6 \pm 0.97$ \\
\hline Indian $\left(600 \mathrm{mg} \mathrm{Kg}^{-1} \mathrm{day}^{-1}\right)$ & $1.03 \pm 0.15^{\text {繁等, }}$ & 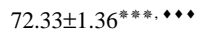 & 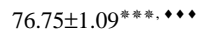 & 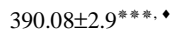 & 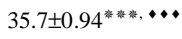 \\
\hline Al-Jouf $\left(600 \mathrm{mg} \mathrm{Kg}^{-1} \mathrm{day}^{-1}\right)$ & 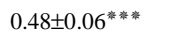 & 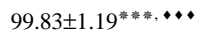 & 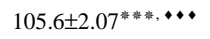 & 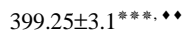 & 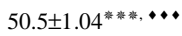 \\
\hline Rayma $\left(600 \mathrm{mg} \mathrm{Kg}^{-1}\right.$ day $\left.^{-1}\right)$ & 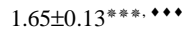 & 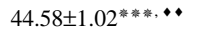 & 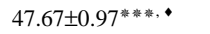 & $361.8 \pm 3.59$ 䄅蔡, $\bullet$ & 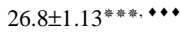 \\
\hline
\end{tabular}

The statistical data were expressed as Mean \pm S.E.M.; number $=12$ rat for each group. TBARs $=$ thiobarbituric acid substances; SOD $=$ Superoxide dismutase; GSH = Reduced glutathione; $\mathrm{TP}=$ Total proteins. $\bullet$ or $=\mathrm{p}<0.05$; $\bullet$ or 慗 $=\mathrm{p}<0.01$; $\bullet \bullet$ or 婳 = compare among different groups vs. saline group while $\bullet=$ compare among different groups vs. ranitidine group

Table 3: Comparison of both ulcer score and gastric lesion index among different studied groups in percentage of inhibition

Treatment

\begin{tabular}{|c|c|c|c|c|}
\hline $\begin{array}{l}\text { (one dose daily for } 14 \text { day) } \\
\text { (in } \mathrm{mm} \text { ) }\end{array}$ & $\begin{array}{l}\text { Ulcer score } \\
(0-5)\end{array}$ & $\begin{array}{l}\text { Percentager } \\
\text { of Inhibition }\end{array}$ & $\begin{array}{l}\text { Gastric } \\
\text { lesion index }\end{array}$ & $\begin{array}{l}\text { Percentager } \\
\text { of Inhibition }\end{array}$ \\
\hline 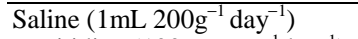 & $4.08+0.23$ & --- & $23.50 \pm 0.74$ & --- \\
\hline Ranitidine (100 mg Kg ${ }^{-1}$ day $^{-1}$ ) & $1.33 \pm 0.36$ 粶核粠. & 67.43 & 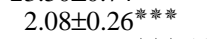 & 91.15 \\
\hline Russian $\left(600 \mathrm{mg} \mathrm{Kg}^{-1}\right.$ day $\left.^{-1}\right)$ & 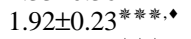 & 53.07 & 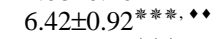 & 72.72 \\
\hline Indian $\left(600 \mathrm{mg} \mathrm{Kg}^{-1} \mathrm{day}^{-1}\right)$ & 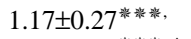 & 71.44 & 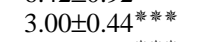 & 87.23 \\
\hline Al-Jouf $\left(600 \mathrm{mg} \mathrm{Kg}^{-1}\right.$ day $\left.^{-1}\right)$ & 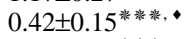 & 89.81 & 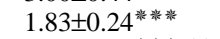 & 92.21 \\
\hline Rayma (600 mg Kg ${ }^{-1}$ day $\left.^{-1}\right)$ & 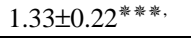 & 67.35 & 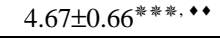 & 80.17 \\
\hline
\end{tabular}

The statistical data were expressed as Mean \pm S.E.M., number $=12$ rat for each group. Ulcer Score represented as follow; $0=$ no erosions, $1=1-3$ small erosion, $2=$ more than 3 small erosion or one large erosion, $3=$ one large erosion and more than 3 small erosion, $4=3-4$ large erosion and $5=$

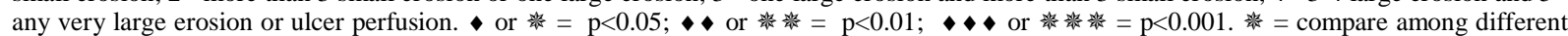
groups vs. saline group while $\bullet=$ compare among different groups vs. ranitidine group

Tissue lipid peroxidation and antioxidant markers: Table 2 showed highly significant decreases in tissue TBARs level in all pretreated groups than saline pretreated group, while a significant increase in tissue TBARs level in all pretreated groups except Al-Jouf shilajit pretreated group when compared to ranitidine treated group as shown Fig. (2A).

In contrast, significant increase in tissue catalase activity in all pretreated groups than saline treated group. Moreover, a significant increase in tissue catalase activity in all treated groups when compared with ranitidine pretreated group especially in both Indian and Al-Jouf shilajit pretreated groups as shown Fig. (2B). Furthermore, stomach tissue SOD activity, GSH and total proteins showed significant increase its activity or levels in all pretreated groups than saline pretreated group. Moreover, a significant increase in its activity or levels in all treated groups when compared with ranitidine pretreated group except in Russian shilajit pretreated group as shown Fig. (2C, $2 \mathrm{D}$ and $2 \mathrm{E}$ ) respectively.

Morphological findings of stomach: In the present study oral administration of ethanol/ $\mathrm{HCl}$ produced severe ulceration. All shilajit and ranitidine treated groups were inhibit both ulcer score and gastric lesion index in various percentages when compared to saline pretreated group. In particular, Al-Jouf shilajit pretreated group showed a greater inhibition of both ulcer score and gastric lesion index than ranitidine pretreated group as shown in Table 3 and Fig. 3A and $3 \mathrm{~B}$ respectively.
Histological findings of stomach: Histological results showed a mucosal lesion, severe disruption to the surface epithelium, deep hemorrhagic erosions and edema of the sub-mucosa layer with leucocyte infiltration in both Saline and Russian shilajit pretreated groups respectively. In addition, Rayma shilajit pretreated groups showed severe disruption to the surface epithelium, hemorrhage and degenerative changes. Moreover, Ranitidine pretreated group showed mild disruption to the surface epithelium mucosa, immune response, with no edema and no leucocytes infiltration of the sub-mucosal layer. A disruption and superficial hemorrhagic erosions to the surface epithelium with no edema, no immune response and no leucocytes infiltration of the normally intact submucosal layer in Indian shilajit sample pretreated group, while, normal intact gastric layer with no disruption to the surface epithelium, no edema, no immune response and no leucocytes infiltration of the sub-mucosal layer observed in Al-Jouf shilajit pretreated group as shown in Fig. 4A-4F.

\section{Anti-microbial activity:}

Inhibition zone: Rayma sample of shilajit at highest concentration $500 \mu \mathrm{g} \mathrm{disc}{ }^{-1}$ only showed strong antibacterial activity against Pseudomonas aeruginosa and a very strong antibacterial effect against Staphylococcus aureus at concentrations of 500, 300, $100 \mu \mathrm{g} \mathrm{disc}{ }^{-1}$ which gave an inhibition zones of $22 \mathrm{~mm}, 20 \mathrm{~mm}, 18$ mm diameters, respectively. In addition, Rayma sample showed strong anti-bacterial effect against Bacillus subtillis at concentrations of 500, 300, $100 \mu \mathrm{g} \mathrm{disc}{ }^{-1}$ having gave inhibition zones of $22 \mathrm{~mm}, 20 \mathrm{~mm}, 17 \mathrm{~mm}$ diameters, respectively. 
Am. J. Biochem. \& Biotech., 8 (1): 25-37, 2012

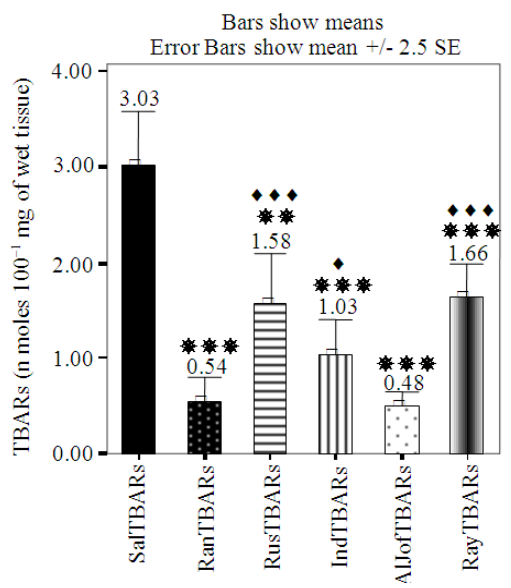

(A)

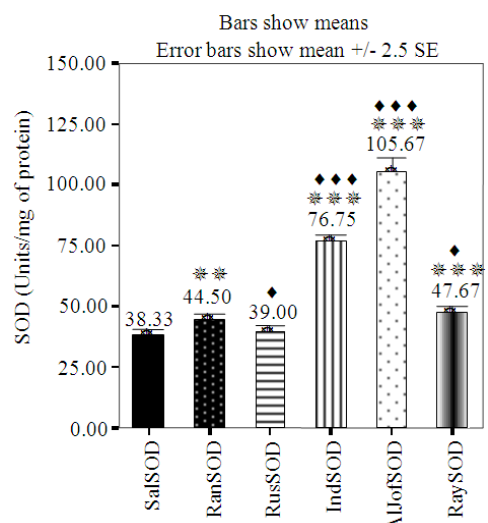

(C)

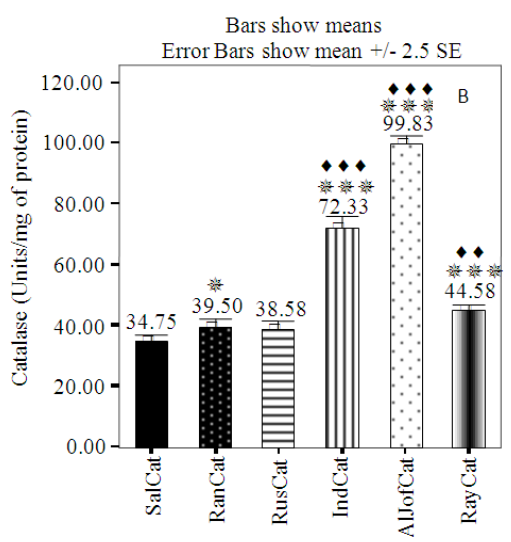

(B)

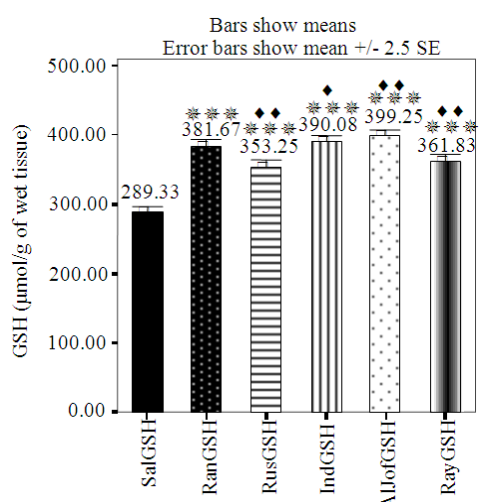

(D)

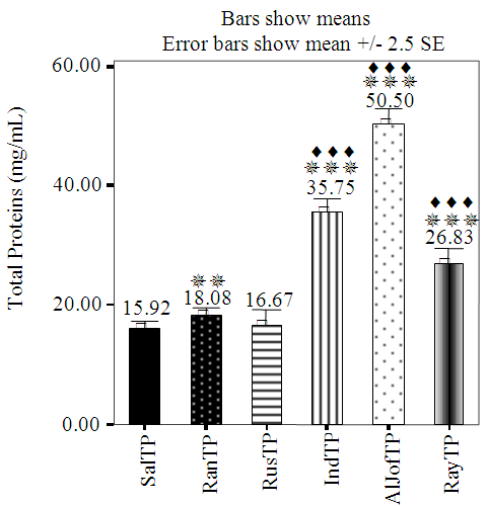

(E)

Fig. 2: Effects of shilajit samples $\left(600 \mathrm{mg} \mathrm{kg}^{-1}\right)$ and ranitidine $\left(100 \mathrm{mg} \mathrm{kg}^{-1}\right)$ pretreatment on stomach tissue oxidant and anti-oxidant activities ( $\mathrm{A}=$ TBARs, $\mathrm{B}=$ Catalase, $\mathrm{C}=\mathrm{SOD}, \mathrm{D}=\mathrm{GSH}$ and $\mathrm{E}=$ total proteins $)$ in rats with ethanol/HCl-induced gastric ulcer. It showed significant decrease in TBARs while increase in catalase, SOD, GSH and total proteins with studied treatments than saline treated group, especially in AlJouf and Indian shilajit treated groups. TBARs = thiobarbituric acid reactive substance; SOD = super oxide dismutase; GSH = reduced glutathione; Sal = saline; Ran = ranitidine; Rus = Russian; Ind = Indian; AlJof = Al-Jouf; and Ray = Rayma 
Am. J. Biochem. \& Biotech., 8 (1): 25-37, 2012

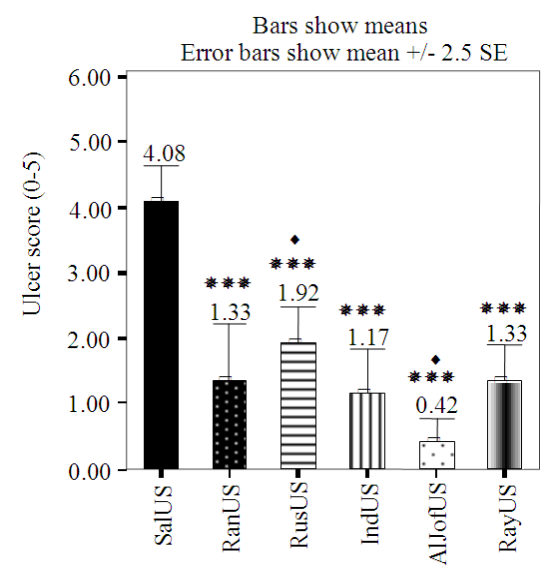

(A)

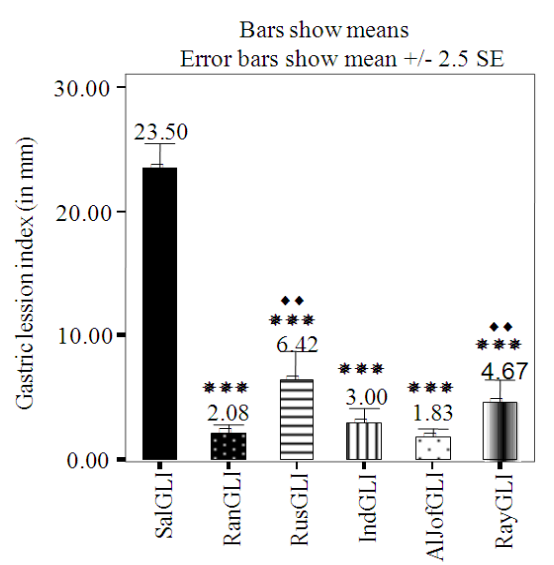

(B)

Fig. 3: Effects of shilajit samples $\left(600 \mathrm{mg} \mathrm{kg}^{-1}\right)$ and ranitidine $\left(100 \mathrm{mg} \mathrm{kg}^{-1}\right)$ pretreatment on both gastric ulcer score (A) and lesion index (B) in rats with ethanol/HCl-induced gastric ulcer. It showed significant decrease in both ulcer score and lesion index with studied treatments than saline treated group, especially in Al-Jouf shilajit treated groups

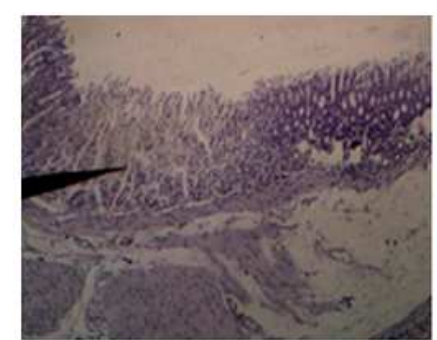

(A)

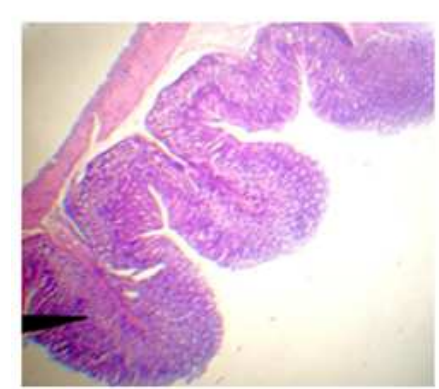

(D)

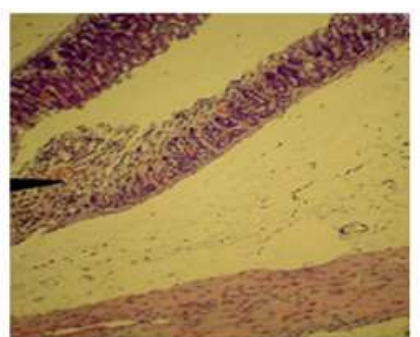

(B)

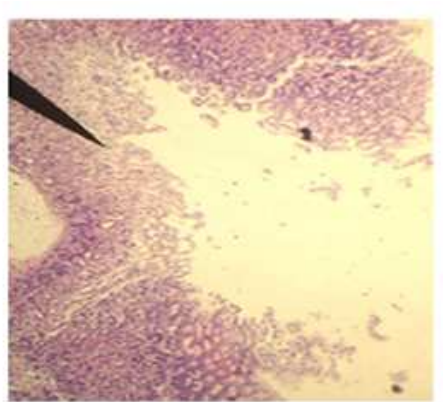

(E)

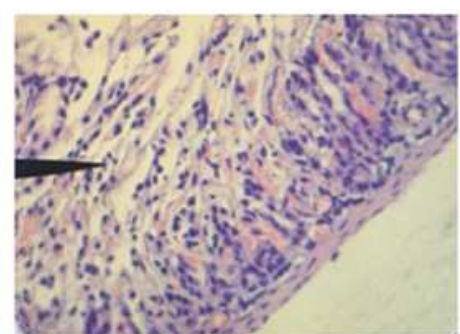

(C)

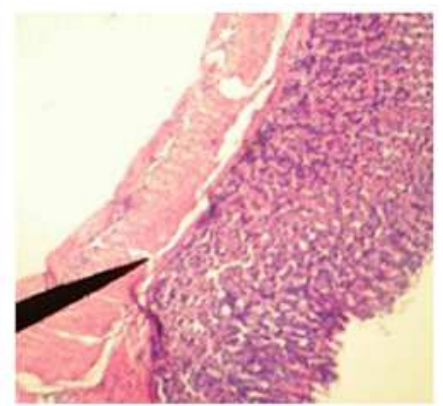

(F)

Fig. 4: Histological section of gastric mucosa in a rat pre-treated; (A) with saline $\left(1 \mathrm{~mL} 200 \mathrm{~g}^{-1}\right)$ : there is mucosal lesion, severe disruption to the surface epithelium, deep hemorrhagic erosions and edema of the sub-mucosa layer with leucocyte infiltration, (B) with Russian shilajit $\left(600 \mathrm{mg} \mathrm{kg}^{-1}\right)$ : there is severe disruption to the surface epithelium, deep hemorrhagic erosions and edema of the sub-mucosa layer with leucocyte infiltration, (C) with Rayma shilajit $\left(600 \mathrm{mg} \mathrm{kg}^{-1}\right)$ : there is severe disruption to the surface epithelium, hemorrhage, degenerative changes, (D) with Ranitidine $\left(100 \mathrm{mg} \mathrm{kg}^{-1}\right)$ : there is mild disruption to the surface epithelium mucosa, immune response, with no edema and no leucocytes infiltration of the sub-mucosal layer, (E) with Indian shilajit $\left(600 \mathrm{mg} \mathrm{kg}^{-1}\right)$ : there is a disruption and superficial hemorrhagic erosions to the surface epithelium, no edema, no immune response and no leucocytes infiltration of the normally intact sub-mucosal layer and (F) with Al-Jouf shilajit $\left(600 \mathrm{mg} \mathrm{kg}^{-1}\right)$ : there is a normal gastric layer with no disruption to the surface epithelium, no edema, no immune response and no leucocytes infiltration of the sub-mucosal layer ( $\mathrm{H}$ and $\mathrm{E}$ stain) 
Am. J. Biochem. \& Biotech., 8 (1): 25-37, 2012

Table 4: Antimicrobial activity of different studied shilajit samples and miconazole nitrate, amoxicillin-clavulanic acid, ofloxacin, netilmicin standards (in $\mathrm{mm}$ of inhibition zone)

\begin{tabular}{|c|c|c|c|c|c|c|c|c|c|c|c|c|c|c|c|c|}
\hline \multirow[b]{4}{*}{ Micro-organism } & & & & \multicolumn{9}{|c|}{ Shilajit sample } & \multicolumn{4}{|l|}{ Standards } \\
\hline & \multicolumn{3}{|c|}{ Russian (Tien-Shan) } & \multicolumn{3}{|c|}{ Indian (Kumoan) } & \multicolumn{3}{|c|}{ Yemen (Al-Jouf) } & \multicolumn{3}{|c|}{ Yemen (Rayma) } & \multirow{3}{*}{$\begin{array}{l}\text { ACA 20- } \\
10 \mu \mathrm{g} \\
\mathrm{disc}^{-1}\end{array}$} & \multirow{3}{*}{$\begin{array}{l}\mathrm{O} \\
5 \mu \mathrm{g} \\
\mathrm{disc}^{-1}\end{array}$} & \multirow{3}{*}{$\begin{array}{l}\text { MN } \\
40 \mu \mathrm{g} \\
\operatorname{disc}^{-1}\end{array}$} & \multirow{3}{*}{$\begin{array}{l}\mathrm{N} \\
30 \mu \mathrm{g} \\
\text { disc }^{-1}\end{array}$} \\
\hline & 500 & 300 & 100 & 500 & 300 & 100 & 500 & 300 & 100 & 500 & 300 & 100 & & & & \\
\hline & $\begin{array}{l}\mu \mathrm{g} \\
\operatorname{disc}^{-1}\end{array}$ & $\begin{array}{l}\mu \mathrm{g} \\
\operatorname{disc}^{-1}\end{array}$ & $\begin{array}{l}\mu \mathrm{g} \\
\operatorname{disc}^{-1}\end{array}$ & $\begin{array}{l}\mu \mathrm{g} \\
\mathrm{disc}^{-1}\end{array}$ & $\begin{array}{l}\mu \mathrm{g} \\
\operatorname{disc}^{-1}\end{array}$ & $\begin{array}{l}\mu \mathrm{g} \\
\operatorname{disc}^{-1}\end{array}$ & $\begin{array}{l}\mu \mathrm{g} \\
\operatorname{disc}^{-1}\end{array}$ & $\begin{array}{l}\mu \mathrm{g} \\
\operatorname{disc}^{-1}\end{array}$ & $\begin{array}{l}\mu \mathrm{g} \\
\operatorname{disc}^{-1}\end{array}$ & $\begin{array}{l}\mu \mathrm{g} \\
\operatorname{disc}^{-1}\end{array}$ & $\begin{array}{l}\mu \mathrm{g} \\
\operatorname{disc}^{-1}\end{array}$ & $\begin{array}{l}\mu \mathrm{g} \\
\operatorname{disc}^{-1}\end{array}$ & & & & \\
\hline $\begin{array}{l}\text { Pseudomonas } \\
\text { aeruginosa }\end{array}$ & - & - & - & - & - & - & - & - & - & 22 & - & - & - & - & - & 9 \\
\hline $\begin{array}{l}\text { Staphylococcus } \\
\text { aureus }\end{array}$ & 17 & 16 & 15 & - & - & - & - & - & - & 22 & 20 & 18 & 16 & 14 & - & 25 \\
\hline Bacillus subtilis & - & - & - & - & - & - & 22 & 20 & 19 & 22 & 20 & 17 & 15 & 15 & - & 24 \\
\hline Escherichia coli & 22 & 19 & 15 & - & - & - & - & - & - & 27 & 25 & 23 & 17 & 22 & - & 26 \\
\hline Candida albican & 25 & 20 & 17 & - & - & - & - & - & - & 24 & 18 & 16 & - & - & 22 & - \\
\hline
\end{tabular}

MN: miconazole nitrate; ACA: amoxicillin-clavulanic acid; O: ofloxacin; N: netilmicin; (-): not detected activity at this amount of shilajit or standards.

Furthermore, Rayma sample of shilajit showed very strong anti-bacterial effect against Escherichia coli at concentrations of 500, 300, $100 \mu \mathrm{g} \mathrm{disc} \mathrm{de}^{-1}$ gave inhibition zones of $27 \mathrm{~mm}, 25 \mathrm{~mm}$ and $23 \mathrm{~mm}$ diameters respectively. Finally, Rayma sample of shilajit was found to be significant antifungal effect against Candida albicans at concentrations of 500, 300, $100 \mu \mathrm{g} \mathrm{disc}^{-1}$ and gave inhibition zones of $24 \mathrm{~mm}, 18$ $\mathrm{mm}, 16 \mathrm{~mm}$ diameter, respectively as shown in Table 4 .

Russian shilajit sample had a moderate antibacterial effect against Staphylococcus aureus at concentrations of $500,300,100 \mu \mathrm{g} \mathrm{disc} \mathrm{d}^{-1}$ giving inhibition zones of 17,16 and $15 \mathrm{~mm}$, respectively. In addition, Russian shilajit sample, showed strong antibacterial effect against Escherichia coli at concentrations of $500,300,100 \mu \mathrm{g} \mathrm{disc}{ }^{-1}$ giving inhibition zones 22, 19, $15 \mathrm{~mm}$ diameters respectively. Moreover, it had very strong anti-fungal effect against Candida albican at concentrations of 500, 300, $100 \mu \mathrm{g}$ disc $^{-1}$ giving inhibition zones of $25 \mathrm{~mm}, 20 \mathrm{~mm}$ and 12 $\mathrm{mm}$ diameters respectively Table 4. Al-Jouf shilajit sample showed a strong anti-bacterial effect against Bacillus subtillis only at concentrations of 500, 300, $100 \mu \mathrm{g} \mathrm{disc}^{-1}$ giving inhibition zones of 22,20 and 18 $\mathrm{mm}$ diameters respectively, while Indian shilajit samples were inert against all tested bacteria and fungi as recorded in Table 4.

Minimal Inhibitory Concentration (MIC): Inferences from the above assay in Table 5A show that MIC of Russian shilajit for Staphylococcus Aureus is $125 \mu \mathrm{g} \mathrm{mL}^{-1}$, Bacillus Subtilis is $1000 \mu \mathrm{g}$ $\mathrm{mL}^{-1}$ and for both Escherichia Coli and Candida Albican is $62.5 \mu \mathrm{g} \mathrm{mL}^{-1}$, while no MIC for both Pseudomonas Aeruginosa within diluted conc. Table 5B showed MIC of Indian shilajit for Bacillus Subtilis, Escherichia Coli and Candida Albican is $1000 \mu \mathrm{g} \mathrm{mL}^{-1}$, while no MIC for both Pseudomonas Aeruginosa and Staphylococcus Aureus within diluted conc.
Table 5A: MIC results of Russian shilajit sample for Pseudomonas Aeruginosa, Staphylococcus Aureus, Bacillus Subtilis, Escherichia Coli and Candida Albican Russian (Tien-Shan) shilajit Concentration $\left(\mu \mathrm{g} \mathrm{mL}^{-1}\right)$ Dilution level

\begin{tabular}{|c|c|c|c|c|c|c|c|c|c|c|}
\hline Micro-organism & 1000 & 500 & 250 & 125 & 62.5 & 31.3 & 15.6 & 7.8 & 3.9 & 1.95 \\
\hline $\begin{array}{l}\text { Pseudomonas } \\
\text { aeruginosa }\end{array}$ & + & + & + & + & + & + & + & + & + & + \\
\hline $\begin{array}{l}\text { Staphylococcus } \\
\text { aureus }\end{array}$ & - & - & - & - & + & + & + & + & + & + \\
\hline Bacillus subtilis & - & + & + & + & + & + & + & + & + & + \\
\hline Escherichia coli & - & - & - & - & - & + & + & + & + & + \\
\hline Candida albican & - & - & - & - & - & + & + & + & + & + \\
\hline
\end{tabular}

MIC; Minimal Inhibitory Concentration, (-); no detected turbidity or growth, (+); detected turbidity or growth

Table 5B: MIC results of Indian shilajit sample for Pseudomonas Aeruginosa, Staphylococcus Aureus, Bacillus Subtilis, Escherichia Coli and Candida Albican

\begin{tabular}{|c|c|c|c|c|c|c|c|c|c|}
\hline \multirow[b]{2}{*}{ Micro-organism } & \multicolumn{9}{|c|}{ Indian (Kumoan) shilajit concentration $\left(\mu \mathrm{g} \mathrm{mL}^{-1}\right)$ dilution level } \\
\hline & 1000 & 500 & 250 & 125 & 62.531 .3 & 15.6 & 7.8 & 3.9 & 1.95 \\
\hline $\begin{array}{l}\text { Pseudomonas } \\
\text { aeruginosa }\end{array}$ & + & + & + & + & ++ & + & + & + & + \\
\hline $\begin{array}{l}\text { Staphylococcus } \\
\text { aureus }\end{array}$ & + & + & + & + & + & + & + & + & + \\
\hline Bacillus subtilis & - & + & + & + & + & + & + & + & + \\
\hline Escherichia coli & - & + & + & + & + & + & + & + & + \\
\hline Candida albican & - & + & + & + & + & + & + & + & + \\
\hline
\end{tabular}
MIC; Minimal Inhibitory Concentration, (-); no detected turbidity or growth, (+); detected turbidity or growth

Table 5C: MIC results of Al-Jouf shilajit sample for Pseudomonas Aeruginosa, Staphylococcus Aureus, Bacillus Subtilis, Escherichia Coli and Candida Albican Al-Jouf (Kumoan) shilajit concentration $\left(\mu \mathrm{g} \mathrm{mL}^{-1}\right)$ dilution level

\begin{tabular}{llllllllllllll} 
Micro-organism & 1000 & 500 & 250 & 125 & 62.5 & 31.3 & 15.6 & 7.8 & 3.9 & 1.95 \\
\hline Pseudomonas & - & + & + & + & + & + & + & + & + & +
\end{tabular} aeruginosa

Staphylococcus +++++++++ aureus

Bacillus subtilis

$\begin{array}{lllllllllll}\text { Bacillus subtilis } & - & - & - & - & - & + & + & + & + & + \\ \text { Escherichia coli } & - & + & + & + & + & + & + & + & + & + \\ \text { Candida albican } & - & + & + & + & + & + & + & + & + & +\end{array}$

MIC; Minimal Inhibitory Concentration, (-); no detected turbidity or growth, (+); detected turbidity or growth

Inferences from the below assay Table 5C: MIC of Al-Jouf shilajit for Pseudomonas Aeruginosa is $1000 \mu \mathrm{g} \mathrm{mL}$, Bacillus Subtilis is $62.5 \mu \mathrm{g} \mathrm{mL}^{-1}$ and for both Escherichia Coli and Candida Albican is $1000 \mu \mathrm{g} \mathrm{mL}^{-1}$, while no MIC for Staphylococcus Aureus within diluted conc. 
Table 5D: MIC results of Rayma shilajit sample for Pseudomonas Aeruginosa, Staphylococcus Aureus, Bacillus Subtilis, Escherichia Coli and Candida Albican Rayma (Kumoan) shilajit Concentration $\left(\mu \mathrm{g} \mathrm{mL}^{-1}\right)$ Dilution level

\begin{tabular}{|c|c|c|c|c|c|c|c|c|c|c|}
\hline \multirow[b]{2}{*}{ Micro-organism } & \\
\hline & 1000 & 500 & 250 & 125 & 62.5 & 31.3 & 15.6 & 7.8 & 3.9 & 1.95 \\
\hline $\begin{array}{l}\text { Pseudomonas } \\
\text { aeruginosa }\end{array}$ & - & - & + & + & + & + & + & + & + & + \\
\hline $\begin{array}{l}\text { Staphylococcus } \\
\text { aureus }\end{array}$ & - & - & - & - & - & + & + & + & + & + \\
\hline Bacillus subtilis & - & - & - & - & + & + & + & + & + & + \\
\hline Escherichia coli & - & - & - & - & - & + & + & + & + & + \\
\hline Candida albican & - & - & - & - & - & + & + & + & + & + \\
\hline
\end{tabular}

MIC; Minimal Inhibitory Concentration, (-); no detected turbidity or growth, (+); detected turbidity or growth

Table 5D showed MIC of Rayma shilajit for Pseudomonas Aeruginosa is $500 \mu \mathrm{g} \mathrm{mL}$, Staphylococcus Aureus is $62.5 \mu \mathrm{g} \mathrm{mL}^{-1}$, Bacillus Subtilis is $125 \mu \mathrm{g} \mathrm{mL}^{-1}$ and for both Escherichia Coli and Candida Albican is $62.5 \mu \mathrm{g} \mathrm{mL}^{-1}$.

\section{DISCUSSION}

Shilajit is generally considered safe in moderate doses and is readily available in the United States both as a stand-alone product and in the traditional formula. It has also compounded in many patent medicines from India (Frawley and Lad, 2004). It is useful in cases of gastrointestinal tract (Nuraliev and Denisenko, 1997), digestive disorders, wound healing and stomach ulcer (Goel et al., 1990).

Toxicity study: Only shilajit doses of $900 \mathrm{mg} \mathrm{kg}^{-1}$ slightly increase body temperature of the mice and 4 mice dead of total 40 mice for that dose of different shilajit samples and no acute toxicity or macroscopic changes in daily body or organ weights were observed using shilajit at dose $600 \mathrm{mg} \mathrm{kg}^{-1}$. The current results in agreement with Talbert (2004) whom reported that shilajit may be utilized safely in clinical practice because shilajit is reported to be quite safe up to a dose of $3 \mathrm{~g} \mathrm{~kg}^{-1}$ (p.o) and $1 \mathrm{~g} \mathrm{~kg}^{-1}$ (intraperitoneal injection) in mice ( $24 \mathrm{~h}$ mortality).

Antiulcer activity: The gastric mucosa is constantly exposed to potentially noxious stimuli of endogenous (acid, pepsin, bile) and exogenous (alcohol, drugs) origin. It is commonly believed that the tolerance of the gastric mucosa to damage, originates from continuously operating defensive mechanisms, which include mucosal blood flow, mucus and bicarbonate secretion and gastric mucosal potential difference. It is generally accepted that it results from an imbalance between aggressive factors (such as acid, pepsin) and the maintenance of the mucosal integrity through the endogenous defense mechanism (Piper and Stiel, 1986). Generally, shilajit has an expected broad biochemical and pharmacological activities due to its contents of fulvic acid and other antioxidant materials. Fulvic Acids (FA) has been taken orally as a therapy for gastritis, stomach ulcers and colitis (Schepetkin et al., 2002; Agarwal et al., 2007).

\section{Biochemical activity:}

Plasma lipids: Above mentioned results, found that; all shilajit pretreated groups showed various effects on plasma lipids in comparison with saline pretreated group. Al-Jouf shilajit pretreated group particularly showed distinct changes in plasma lipogram than those with Ranitidine pretreated group. This biochemical effect may attribute in general to presence of the bioactive dibenzo-alpha-pyrones along with humic and fulvic acids which acted as carrier molecules for the active ingredients and act as antioxidant (Ghosal, 1990), so decrease free radicals and augments protein synthesis, SOD, catalase, GSH roles to maintains normal levels of both LDLc and HDLc and subsequently normal total cholesterol and protects enzymes like plasma lipoprotein lipase to improve TGs levels.

Tissue lipid peroxidation and antioxidant markers: Several studies have shown alterations in the antioxidant status following ulceration, implying that free radicals may be associated with ethanol induced gastric mucosal damage in rats (Repetto and Llesuy, 2002). So, drugs with multiple mechanisms of protective action, including antioxidant properties, may be beneficial in minimizing tissue injury in human disease (Halliwell, 1991).

Results of the present study showed highly significant increase of SOD, catalase activities and GSH level while decrease of TBARs in all shilajit pretreated groups than saline pretreated group especially in Al-Jouf and Indian shilajit pretreated groups than either of Ranitidine or other pretreated groups. Hence, an increase of TBARs level and consuming each of SOD, catalase, GSH within gastric mucosal cells of saline pretreated groups become clear and in agreement with results of Maity et al. (2003). Regeneration of these gastric mucosal antioxidant parameters in all shilajit pretreated groups (in spite of varying percentage) might be explained by presence of fulvic acid, dibenzo-a-pyrones and tannic acid as a major antiradical constituent of shilajit water extract and fulvic acid significantly increases SOD, catalase and glutathione peroxidase levels and activity (Ghosal et al., 1993; Bhattacharya et al., 1997; Kaul and Khanduja, 1998; Schepetkin et al., 2002). Moreover, the presence of several triterpenes and phenolic compounds (Talbert, 2004; Tiwari et al., 2001) led us to investigate the effect of shilajit on lipid peroxidation, because in ulcer, free radicals are 
involved and compounds of this chemical structure, have a free radical scavenging property.

Morphological and histological findings of stomach: Peptic ulcer occurs due to imbalance between offensive (acid-pepsin secretion. H.pylori, bile, increased free radicals and decreased antioxidants) versus impaired mucosal resistance (mucus, bicarbonate secretion, prostaglandins, blood flow and the process of restitution and regeneration after cellular injury) (Goel and Bhattacharya, 1991; Akhtar et al., 1992).

The current study revealed that oro-gastric ethanol/HCl intubation for only one day resulted in production of gastric mucous membrane erosions evidenced macroscopically by significant rise in erosion scores and microscopically by areas of superficial and deep hemorrhagic erosions, necrosis of gastric mucous membrane in saline pretreated group. This is in accordance with the other studies using ethanolinduction of peptic ulcer (Sheeba and Asha, 2006). Both ulcer score and gastric lesion index data showed that both Al-Jouf and Indian shilajit pretreated samples had a greater inhibition \% on both factors than either Russian or Rayma shilajit pretreated samples when compared to either Ranitidine or saline pretreated groups. We assume as mentioned above that this difference in activity of shilajit samples was due to a difference in their constituent $\%, \mathrm{pH}$ values and geographical origin of each sample.

The presence of polyphenols compounds such as fulvic acids, 4-methoxy-6-carbomethoxybi-phenyl, tirucallane-type triterpenoids and benzoic acid in shilajit samples have antioxidant activity, cellular repairing and regeneration, played very important role in decrease acid pepsin secretion, cell shedding, gastric ulcer index, tendency to increase mucin secretion and carbohydrate/protein ratio which have very important role as anti-oxidant effect and anti-inflammatory as reported by Shenyuan (1988); Goel et al. (1990); Czinner et al. (2001); Rajic et al. (2001); Tewari et al. (2001) and Talbert (2004), so they stated its use in gastric ulcer and wound healing.

In context, anti-anxiety activity and anti-stress effects of shilajit has a role in healing of gastric ulcer as stated by Frawley and Lad (2004) whom indicate that shilajit has significant anxiolytic and anti-stress activity as reported by). Due to bacteriostatic and antiinflammatory action, shilajit extract facilitates the process of wound cleaning from necrotic tissues, granulation and epithelization and decreases the period of wound healing (Shakirov, 1969; Tazhimametov et al., 1987). Shilajit is truly a remarkable substance with a long history of human usage for healing and should be subjected to further investigations (Frawley and Lad, 2004).
Antimicrobial activity: The results of the current study showed that Rayma shilajit samples had strong and broad antimicrobial effect on tested microorganisms even against Staphylococcus aureus, of antibiotic resistance and the primary cause of this effect might be due to higher $\mathrm{pH}$ values of Rayma sample (8.25) which increases free radical formation that decompose microorganism membranes by lipid peroxidation effects. The same cause might be refer to anti-microbial effect of Russian shilajit sample $(\mathrm{pH}=7.61)$. While AlJouf and Indian shilajit sample was of lower and no antimicrobial effect respectively than other samples. A second proposed cause of antimicrobial effect of studied shilajit sample is due to variable concentration and antimicrobial effect of fulvic acidic electrolytic value. Fulvic acid increases permeability of biomembranes, which means that it can sensitize cell membranes for better absorption or assimilation of other active constituents. This effect will affect on intracellular homeostasis and disturb both electrochemical gradient and osmolarity within microbial cell leading to its lysis. Fulvic acid is a polyelectrolyte which means "much electric". The value of an electrolyte can be shown by an experiment that was done by Shenyuan (1988) on amoeba, visually concluded that the form and structure of the amoeba had disintegrated and it was for all purposes dead.

The current results in the same line with Shakirov (1969) whom reported that shilajit possesses the antimicrobial activity with respect to different strains of the widespread pyogenic microbes (staphylococci, streptococci, coliform bacteria, enterococci, Proteus) and with Muratova and Shakirov (1968) whom applied shilajit for treatment of suppurative wounds). The bactericidal activity of shilajit extract may be related to some of its components, such as benzoic and fulvic acids (Rensburg et al., 2000).

This difference among shilajit samples in its antiulcer and antimicrobial effects, is due to a difference in climatic conditions and types of plants and herbs are found in the regions which it comes from, so shilajit samples from different regions of the world can have markedly different physiological properties on the basis of its major organic constituents as reported by many authors (Galimov et al., 1986; Ghosal et al., 1991). Shilajit from India decreased the volume of gastric secretion and acid output, whereas samples from Russia did not. Therefore, for treating human ulcers, the geographical origin of the shilajit is probably important (Ghosal et al., 1992).

\section{CONCLUSION}

Then, we could report that all studied shilajit samples in varying degrees have hypolipidemic, anti- 
oxidant, antiulcer, regenerative and repairing effects on ethanol/HCl induced ulcer in rats. The antiulcer effect of shilajit especially Al-Jouf and Indian shilajit samples might be due combined biochemical effects including antioxidant, antimicrobial, anti-inflammatory, antistress, anti-anxiety, healing and regenerative effects. However, further investigations are required for its exact mechanism of action before many of shilajit actions can be affirmed.

\section{ACKNOWLEDGEMENT}

We would like to thank technician staff in histology department of Medicine College, Central animal house in Science College and Animal ethical committee, of Sana'a University, Yemen for their help during the experiments.

Funding: There is no any funding for the current study.

Conflict of interest: The authors declare that there are none conflict of interest.

\section{REFERENCES}

Agarwal, S.P., R. Khanna, R. Karmarkar, M.K. Anwer and R.K. Khar, 2007. Shilajit: A review. Phytother. Res., 21: 401-405. PMID: 17295385

Akhtar, M.S., A.H. Akhtar and M.A. Khan, 1992. Antiulcerogenic effects of Ocimum basilicum extracts, volatile oils and flavonoid glycosides in albino rats. Int. J. Pharmacognosy, 30: 97-104. DOI: $10.3109 / 13880209209053966$

Akilandeswari, S., R. Senthamarai, R. Valarmathi, S. Shanthi and S. Prema, 2010. Screening of Gastric Antiulcer Activity of Sida acuta Burm. Int. J. PharmTech. Res., 2: 1644-1648.

Ali, M., I. Sahrawat and O. Singh, 2005. Phytochemical investigation of Shilajit. India. J. Chem., 43B: 2217-2222. DOI: 10.1002/chin.200506208

Bhattacharya, S.K., K.S. Satyan and A. Chakrabarti, 1997. Effect of Trasina, an Ayurvedic herbal formulation, on pancreatic islet superoxide dismutase activity in hyperglycaemic rats. Indian $\mathrm{J}$. Exp. Biol., 35: 297-299. PMID: 9332177

Czinner, E., K. Hagymasi, A. Blazovics, A. Kery and E. Szoke et al., 2001. The in vitro effect of Helichrysi flos on microsomal lipid peroxidation. J. EthnoPharmacol., 77: 31-35. PMID: 11483375

Elstner, E.F. and A. Heupel, 1976. Inhibition of nitrite formation from hydroxylammoniumchloride: A simple assay for superoxide dismutase. Anal. Biochem, 70: 616-620. DOI: 10.1016/00032697(76)90488-7
Frawley, D. and V. Lad, 2004. The Yoga of Herbs: An Ayurvedic Guide to Herbal Medicine. 2nd Edn., Motilal Banarsidass, Delhi, ISBN: 8120811720, pp: 265.

Galimov, E.M., L.A. Kodina, L.N. Vlasova, T.K. Velyukhanova and O.L. Bazilevskaja, 1986. Geochemistry of mummiyo. Geochemistry.

Ghosal, S., 1990. Chemistry of Shilajit, an immunemodulatory ayuvedic rasayana. Pure Applied Chem., 62: 1285-1288.

Ghosal, S., J. Lal and S.K. Singh, 1991. The core structure of shilajit humus. Soil Biol. Biochem., 23: 673-680. DOI: 10.1016/0038-0717(91)90082-U

Ghosal, S., J. Lal, A.K. Jaiswal and S.K. Bhattacharya, 1993. Effects of Shilajit and its active constituents on learning and memory in rats. Phytother. Res., 7: 29-34. DOI: $10.1002 /$ ptr.2650070109

Goel, R.K. and S.K. Bhattacharya, 1991. Gastroduodenal mucosal defense and mucosal protective agents. Indian J. Exp. Biol., 29: 701-714. PMID: 1769712

Goel, R.K., R.S. Banerjee and S.B. Acharya, 1990. Anti-ulcerogenic and anti-inflammatory studies with shilajit. J. Ethno-Pharmacol., 29: 95-103. DOI: 10.1016/0378-8741 (90)90102-Y

Halliwell, B., 1991. Antioxidant effects, A basis for drug selection? Drugs, 42: 569-605. PMID: 1723362

Jung, C.R., I.A. Schepetkin, S.B. Woo, A.I. Khlebnikov and B.S. Kwon, 2002. Osteoblastic differentiation of mesenchymal stem cells by mumie extract. Drug Dev. Res., 57: 122-133. DOI: 10.1002/ddr.10120

Kaneria, M., Y. Baravalia, Y. Vaghasiya and S. Chanda, 2009. Determination of antibacterial and antioxidant potential of some medicinal plants from saurashtra region, India. Indian J. Pharm. Sci., 71: 406-412. PMID: 20502546

Kaul, A. and K.L. Khanduja, 1998. Polyphenols inhibit promotional phase of tumorigenesis: Relevance of superoxide radicals. Nutr. Cancer, 32: 81-85. PMID: 9919616

Laine, L., K. Takeuchi and A. Tarnawski, 2008. Gastric mucosal defense and cytoprotection: Bench to bedside. Gastroenterology, 135: 41-60. PMID: 18549814

Link, E.M., 1988. The mechanism of $\mathrm{pH}$-dependent hydrogen peroxide cytotoxicity in vitro. Arch. Biochem. Biophy., 265: 362-372. DOI: 10.1016/0003-9861(88)90139-7

Lowry, O.H., N.J. Rosenbrough, A.L. Farr and R.J. Randall, 1951. Protein measurement with the Folin phenol reagent. J. Biol. Chem., 193: 265-275. PMID: 14907713 
Maity, S., T. Chaudhuri, J.R. Vedasirmoni and D.K. Granguly, 2003. Cytoprotection mediated antiulcer effect of tea root extract. Indian J. Pharmacol., 35: 213-219.

Muratova, K.N. and D.S. Shakirov, 1968. Clinical treatment of suppurative wounds with Mumie. Surgery (Moscow), 44: 122-124. PMID: 5744991

Murthy, K.R.S., 1995. Astanga Hrdayam. 2nd Edn., Krishnadas Academy, Varanasi, pp: 596.

Nuraliev, Y. and H. Denisenko, 1997. Mumie and its medicinal properties. Dushanbe.

Ohkawa, H., N. Ohishi and K. Yagi, 1979. Assay for lipid peroxides in animal tissue by this thiobarbituric acid reaction. Anal. Biochem., 95: 351-358. PMID: 36810

Oyagi, A., K. Ogawa, M. Kakino and H. Hara, 2010. Protective effects of a gastrointestinal agent containing Korean red ginseng on gastric ulcer models in mice. BMC Complementary Altern. Med., 10: 45-45. PMID: 20718962

Piezzi, R., J. Guzman, T. Guardia, M. Pestchanker and E. Guerreiro et al., 1992. Dehydroleucodine prevents ethanol-induced necrosis in the rat gastric mucosa. A histological study. Microsc. Electron. Biol. Celular, 16: 45-55. PMID: 1293482

Piper, D.W. and D. Stiel, 1986. Pathogenesis of chronic peptic ulcer, current thinking and clinical implications. Med. Prog., 2: 7-10.

Pucaj, K., H. Rasmussen and M. Møller, 2011. Preston T. Safety and toxicological evaluation of a synthetic vitamin K2, menaquinone-7. Toxicology Mechanisms Methods, 21: 520-532. PMID: 21781006

Quinto, E.A. and M.G. Santos, 2005. Microbiology, a guidebook to plant screening: Phytochemical and biological. UST Publishing House, Manila.

Rainsford, K.D., 1984. Side effect of anti-inflammatory analgesic drugs, epidemiology and gastrointestinal tract. Trends Pharmacol. Sci., 5: 156-159.

Rajic, A., T. Akihisa, M. Ukiya, K. Yasukawa and R.M. Sandeman et al., 2001. Inhibition of trypsin and chymotrypsin by antiinflammatory triterpenoids from Compositae flowers. Planta. Med., 67: 599-604. PMID: 11582534

Rensburg, C.E.V., A. Van Straten and J. Dekker, 2000. An in vitro investigation of the antimicrobial activity of oxifulvic acid. J. Antimicrob. Chemother., 46: 853. PMID: 11062218

Repetto, M.G. and S.F. Llesuy, 2002. Antioxidant properties of natural compounds used in popular medicine for gastric ulcers. Brazilian J. Med. Biol. Res., 35: 523- 534. PMID: 12011936
Schepetkin, I.A., A.I. Khlebnikov and B.S. Kwon, 2002. Medical drugs from humus matter: Focus on mumie. Drug Develop. Res., 57: 140-159. DOI: 10.1002/ddr. 10058

Schepetkin, I.A., A.I. Khlebnikov, S.Y. Ah, S.B. Woo and C.S. Jeong et al., 2003. Characterization and biological activities of humic substances from mumie. J. Agric. Food Chem., 51: 5245-5254. PMID: 12926866

Sedlak, J. and R.H. Lindsay, 1968. Estimation of total, protein-bound and non protein sulfhydryl groups in tissue with Ellman's reagent. Anal Biochem., 25: 192-205. PMID: 4973948

Shakirov, D.S., 1969. Experiment treatment of infected wounds with Mumie asil. Exp. Surg. Anesthes., 14: 36-39. PMID: 5385791

Sheeba, M.S. and V.V. Asha, 2006. Effect of cardiospermum halicoabulum on ethanol-induced gastric ulcers in rats. J. Ethinopharm., 106: 105110. PMID: 16469462

Shenyuan, Y., 1988. Fulvic Acid 4; in Application of Fulvic acid and its derivatives in the fields of agriculture and medicine; 1st Ed. June 1993.

Shujaa, N., Z.S. Zadori, A.Z. Ronai, I. Barna and Z. Mergl et al., 2009. Analysis of the effect of neuropeptides and cannabinoids in gastric mucosal defense initiated centrally in the rat. J. Physiol. Pharmacol., 60: 93-100. PMID: 20388951

Talbert, R., 2004. Shilajit; a materia medica monograph. A paper submitted in partial fulfillment of the requirements for the degree of California College of Ayurveda, Grass Valley, California.

Tazhimametov, B.T., M.U. Usmanov, K.A. Dzhuraev, N.I. Sharipov and K. Zulfikarov, 1987. Effect of Mumie on the healing of suppurative wounds. Clin. Surg., 1: 51-52. PMID: 3560681

Tiwari, P., P. Ramarao and S. Ghosal, 2001. Effects of Shilajit on the development of tolerance to morphine in mice. Phytother. Res., 15: 177-179. PMID: 11268125

Trinder, P., 1969. Estimation of triacylglycerol. Ann. Clin. Biochem., 6: 24-27.

Wieland, H. and D. Siedel, 1981. HDL cholesterol estimation. Artzl. Lab., 27: 141-154.

Zoppi, F. and D. Fellini, 1976. Cholesterol estimation. Clin. Chem., 22: 690-691. 